B. B. Auмa, аспірант кафедри економічної політики та врядування, Начіональна академія державного управління при Президентові Украӥни ORCID ID: 0000-0002-7540-3491

DOI: $10.32702 / 2306-6814.2020 .5-6.182$

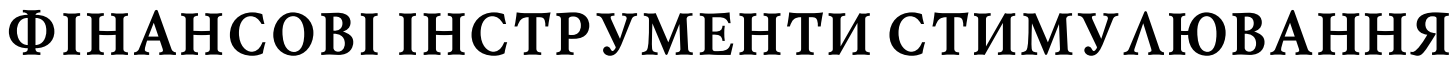

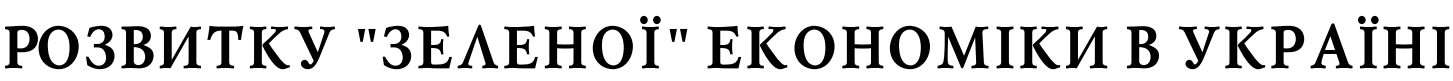

\author{
V. Dyma, \\ postgraduate student, Economic Policy and Governance Department, \\ National Academy of Public Administration under the President of Ukraine
}

\section{FINANCIAL INSTRUMENTS TO PROMOTE GREEN ECONOMY DEVELOPMENT IN UKRAINE}

\begin{abstract}
Статтю присвячено аналізу теоретичних та практичних засад розвитку зелених фінансів, а також перспектив запровадження дієвих фінансових інструментів у сфері розвитку "зеленої" економіки в Україні. Значну увагу приділена огляду фінансових інструментів, які потенційно можуть бути застосовані в Україні з метою стимулювання залучення інвестицій в зелені сектори економіки на основі досвіду впровадження стимулюючих механізмів розвитку "зеленої" економіки урядами європейських країн. Це стосується низки бюджетно-податкових, фінансових інструментів, зокрема таких: "зелені" тарифи, податок на СО2, екологічні податки, "зелені" облігації тощо. Автор наголошує на необхідності розробки стратегії розвитку "зелених" фінансів, реалізація якої має спрямовуватися на вдосконалення нормативно-правової бази, правил та процедур зеленого фінансування, створення інституційної бази зелених фінансів (фінансових установ, організацій тощо), залучення фінансування з Зеленого кліматичного фонду (Green Climate Fund), розробку нових зелених фінансових інструментів, інтеграцію до глобальної системи зелених фінансів та створення відповідної інфраструктури.
\end{abstract}

Introduction: In recent years, the concept of a green economy in the context of sustainable development has become particularly important for Ukraine, because it is within the framework of the implementation of this concept that the key prospects for the development of the Ukrainian economy and the possibility of achieving a high level of well-being of citizens while preserving the environment for future generations. The transition towards a "Green Economy" requires investment and implementation of the new financial instruments to intensify green growth of Ukrainian economy. In Ukraine there is a lack of such instruments and the government should elaborate new policy to green the economy. State policy to stimulate green economy development through fiscal and monetary impact should include, in particular, the development of financial instruments to support green growth by accumulating and channeling green investment into priority industries.

Research: The green investment market in Ukraine is only at an early stage of its development, characterized by extremely limited resources and a short list of available financial instruments that can be used to attract investment in green projects. The current situation requires vigorous action by the state to create a green finance sector in order to secure long-term green economic growth, including the introduction of a number of financial instruments to attract financing to environmentallyfriendly projects.

The international and European experience in introducing incentives for green economy development demonstrates the use of a number of financial instruments, in particular the so-called "green tariffs" and "green bonds". If green tariffs for electricity production from renewable energy sources have been operating in Ukraine for more than 10 years, then such a tool as "green bonds" is a novelty for the domestic financial market. Given the current economic conditions, the prospects 
for greening the domestic economy, which means improving the sectoral and technological structure of Ukraine's economy, will depend on initiatives by the government and other central government bodies to improve existing and put in place new stimulus mechanisms.

A positive step for the development of renewable energy in Ukraine was the adoption of Law No. 8449-d on "green" auctions, which creates competitive conditions for market participants. The system of "green" auctions will allow set a fair market price for "clean" electricity; reduce the cost of green electricity for the consumers; to create competition between market players.

Recently, a new draft law № 2284 as of 17.10.2019 appeared to introduce green bonds in Ukraine and set rules for participants in this market. Adoption of this bill will allow launching in Ukraine a new tool that will give impetus to the implementation of green projects, and will also become an additional source of investment resources for sustainable development.

Conclusion: In order to ensure sustainable development and implementation of the concept of a "green" economy, Ukraine needs to continue its work on improving the legal and organizational mechanisms to stimulate investment attraction into promising, environmentally sound sectors of the economy.

Ключові слова: "зелені" фрінанси, фрінансові інструменти, "зелена" економіка, "зелені" облігації, "зелений" mapupb.

Key words: green finance, financial instruments, green economy, green bonds, green tariffs.

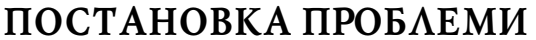

Останні роки концепція "зеленої" економіки в контексті сталого розвитку набуває особливо важливого значення для України, оскільки саме в рамках реалізації даної концепції вбачаються ключові перспективи розвитку економіки України та можливості досягнення високого рівня добробуту громадян з одночасним збереженням навколишнього природного середовища для прийдешніх поколінь. Державна політика стимулювання розвитку "зеленої" економіки серед бюджетно-податкових та грошово-кредитних методів впливу має передбачати, зокрема й розвиток фрінансових інструментів для підтримки зеленого зростання шляхом акумуляції та спрямування в пріоритетні галузі економіки "зелених" інвестицій. Ринок "зелених" інвестицій в Україні перебуває лише на початковому етапі свого розвитку, характеризується деформованістю, вкрай обмеженими ресурсами та переліком доступних фрінансових інструментів, що можуть бути використані для залучення інвестицій в "зелені" проекти. Ситуація, що склалася, потребує активних дій з боку держави щодо створення сектору "зелених" фрінансів з метою забезпечення довгострокового зеленого економічного зростання, зокрема запровадження низки фрінансових інструментів для залучення фінансування у екологоорієнтовані проекти.

\section{АНААІЗ АОСАІАЖЕНЬ ТА ПУБАІКАЦІЙ}

Теоретичні та практичні аспекти, зарубіжні практики та досвід практичної реалізації концепції "зеленої" економіки досліджують багато вітчизняних вчених, зокрема: Т. Буренко, Б. Буркинський, Т. Галушкіна, Н. Захаркевич, Д. Клиновий, В. Потапенко, Л. Мельник, В. Мороз [9], Н. Олійник, Є. Хлобистов та ін. Однак, питання впровадження фрінансових інструментів реалізації стратегій розвитку "зеленої" економіки потребує подальшого поглибленого аналізу, ретельного вивчення і наукового осмислення з метою вироблення рекомендацій для їх запровадження в практичну діяльність суб'єктів ринку.

\section{META CTATTI}

Метою статті $€$ аналіз теоретичних та практичних засад розвитку зелених фрінансів, а також перспектив запровадження дієвих фрінансових інструментів у сфрері розвитку "зеленої" економіки в Україні.

\section{ВИКААА ОСНОВНОГО МАТЕРІААУ АОС $\triangle$ ІАЕННЯ}

Сьогодні весь світ рухається в напрямі розбудови економічних систем, що розвиваються та зростають за рахунок інтенсиорікації технологічних змін, фрормування та реалізації держаної політики, яка сприяє появі нових джерел економічного зростання шляхом створення необхідних умов для залучення інвестицій, впровадження інновацій у пріоритетні галузі економіки та розвитку екологоорієнтованих інноваційних проектів на регіональному та місцевому рівнях. Водночас ключову роль у реалізації такої моделі економічного зростання відіграє розвинений фрінансовий сектор з широким набором фрінансових інструментів, що сприяють активізації інвестиційних процесів, екологізації бізнесу і який стало прийнято називати "сектором зелених фрінансів або зеленими фрінансами".

Зелені фрінанси можна розглядати з двох точок зору. По-перше, зелені фрінанси можуть відігравати певну роль у пом'якшенні екологічних збитків, особливо наслідків впливу змін клімату на економічну систему та суспільство.

По-друге, зелені фрінанси можуть грати роль як цільового фрінансування, що підтримує зелене зростання. Оскільки зелене зростання - це нова парадигма економічного зростання, яка поєднує екологічну стійкість та економічне зростання, для її реалізації необхідна підтримка фрінансової системи, яка відповідає потребам капітального фрінансування галузей економіки, придатних для "озеленення" [1].

Водночас $є$ певні особливості здійснення зелених інвестицій в різних галузях та сорерах підприємницької 
Таблиця 1. Характеристика фінансових інструментів, що сприяють розвитку "зеленої" економіки

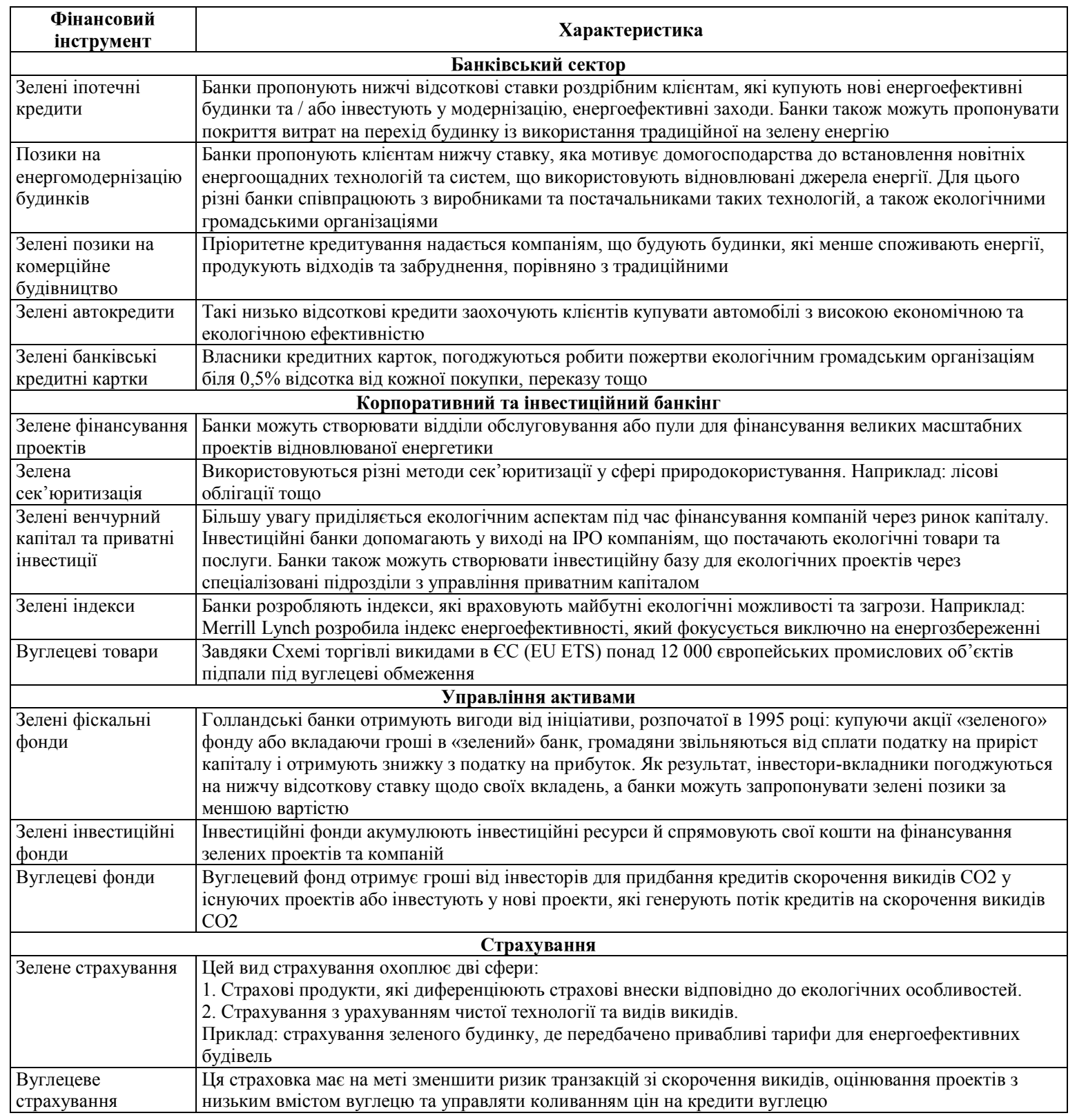

Джерело: складено автором на основі [8].

діяльності. Так, інвестиції в зелені галузі мають високий рівень ризику та невизначеності, оскільки більшість зелених галузей формуються більшою мірою за рахунок нематеріальних активів, ніж матеріальних, а також зорієнтовані на потенціал майбутнього зростання в довгостроковій перспективі.

Крім того, існує інфрормаційна асиметрія між інвесторами та компаніями, що працюють у галузях "зеленої" економіки, що може спричинити дисбаланс у обсягах транзакцій та "відмови" ринку капіталу. Тому для підтримки зеленого зростання потрібен новий підхід, який відрізняється від традиційних фрінансів.

Водночас суттєво зростає роль держави та уряду в забезпечення фрінансової підтримки розвитку зелених галузей, особливо на початкових стадіях реалізації проектів. Однак в умовах бюджетних обмежень уряд не завжди спроможний забезпечити дієву бюджетну підтрим- ку. В цих умовах роль зелених інвестицій приватного сектору досить значна. Однак за існуючого фінансового механізму в зелені проекти важко інвестувати, оскільки ризики та потенційна дохідність на вкладений капітал відрізняється від інвестування у традиційні галузі. Тому потрібно розробляти стратегії розвитку зелених фрінансів, що зокрема включатимуть: вдосконалення нормативно-правової бази, правил та процедур зеленого фрінансування, створення інституційної бази зелених фрінансів (фінансових установ, організацій тощо), використання Зеленого кліматичного фонду (Green Climate Fund), розробку нових зелених фрінансових інструментів, інтеграцію до глобальної системи зелених фрінансів та створення відповідної інфраструктури.

Завдяки тенденції до зростання ролі та попиту на зелені фрінансові інструменти все більше фрінансових установ залучаються до фрінансування зелених ініціатив 
та проектів. Фінансовий бізнес у сорері "зеленої" економіки можна розділити на чотири категорії або сегменти: банківський бізнес, корпоративний та інвестиційний банкінг, управління активами та страхування.

Крім базових фрінансових інструментів, важливу роль у розвитку "зеленої" економіки можуть відігравати й похідні фрінансові інструменти або деривативи (ф'ючерси, опціони тощо). Компанії, що працюють у секторі зелених інвестицій можуть використовувати цілий ряд похідних інструментів з метою хеджування ризиків, пов'язаних, зокрема зі зміною погодних умов. Наприклад, американський інвестиційний банк Goldman Sachs пропонує похідні фінансові інструменти, які можна використовувати для зменшення ризику, пов'язаного з несприятливими або непередбачуваними погодними умовами. Деривативи на зміну погодних умов або деривативи на вітер та інші подібні інструменти дозволяють виробникам вітроенергетики хеджувати ризики у разі неможливості виробництва електроенергії, а значить отримувати дохід в умовах відсутності вітру. Такі фрінансові установи, як ABN AMRO, Rabobank та Goldman Sachs активно працюють на цих ринках.

Міжнародний та європейський досвід впровадження стимулюючих механізмів розвитку "зеленої" економіки свідчить про використання урядами низки бюджетно-податкових, фрінансових інструментів, зокрема таких: "зелені" тарифи, податок на СO2, екологічні податки, "зелені" облігації тощо.

"Зелений" тарифр - це спеціальна ціна, за якою купується енергія, вироблена з відновлюваних джерел енергії - гідроелектростанціями, сонячними, вітровими або біостанціями.

Стимулювання виробництва за допомогою "зеленого" тарифу поширюється майже на всі відновлювані джерела енергії (за винятком електроенергії, виробленої великими гідроелектростанціями). Водночас всю відновлювану енергетику розподілено за двома групами:

1) електроенергія, щодо якої законом установлений гарантований мінімальний "зелений" тариф (енергія вітру, сонця, біомаси та малих ГЕС);

2) електроенергія, на яку гарантований мінімальний "зелений" тарифр не поширюється [5].

Україна у світлі глобальних економічних індексів займає не високі рейтинги та характеризується наявністю низки інституційних фракторів, які негативно впливають на розвиток національної економіки [6]. Водночас в Україні є такі механізми стимулювання виробництва відновлюваної електроенергії: "зелений" тарифр; пільги в оподаткуванні; пільговий режим приєднання до електричної мережі. Так, на сьогодні в економіку України залучено понад 4 млрд євро "зелених" інвестицій за 5 років, що свідчить наскільки затребуваними та успішними є проекти у цих сорерах у країні. Це дає значний поштовх для активізації економічних процесів. Схема стимулювання виробництва електроенергії за допомогою "зеленого" тарифу встановлена до 01.01.2030р. та поширюється на суб'єктів господарювання, які виробляють електроенергію з відновлюваних джерел енергії на електростанціях, введених в експлуатацію в період ії чинності [5].

В Україні відзначається тенденція до збільшення обсягу об'єктів відновлюваної електроенергетики. За даними Держенергоефективності станом на 1 жовтня 2019 року загальний обсяг об'єктів відновлюваної електроенергетики, що працюють за "зеленим" тарифом становить 4935 МВт. (з них найбільша частка СЕС 3420 МВт, ВЕС - 932 МВт). 3 початку 2015 р. введено 3 968 МВт та залучено близько 3,4 млрд Євро інвестицій. Така висока динаміка пояснюється передусім тим, що відповідно до законодавства, 2019 р. це останній рік коли ті, хто побудує нові потужності, встигнуть отримати максимально високий "зелений" тариф, а саме на сонце 18 євроцентів/КВт*г (близько 5 грн за КВт*г), на вітер 11,6 /КВт*г (близько 3,3 грн за КВт*г), за якими будуть розраховуватися аж до 2030 року [2].

Водночас, зростання обсягу чистої енергії при існуючих правилах створює ряд серйозних проблем. Поперше, сьогодні в Україні склалася ситуація, коли діють одні з найвищих "зелених" тарифів у світі. По-друге, вартість технології суттєво падає через масове виробництво, а "зелений" тариф в Україні залишається фріксованим. Тому різниця між реальною вартістю і тарифом стає надприбутками, за які держава в особі ДП "Енергоринок" сплачує приватним компаніям.

На нашу думку, позитивним кроком з боку держави для вирішення проблеми дорогих тарифрів та розвитку відновлюваних джерел енергії в Україні стало прийняття закону №8449-д про "зелені" аукціони, що створює конкурентні умови для учасників ринку шляхом запровадження аукціонів, тендерів передбачено для більшості типів проектів "Керівними принципами 2014 року щодо державної допомоги для захисту навколишнього середовища та енергетики" (EEAG 2014-2020). Закон відкриває новий етап розвитку відновлюваної енергетики: від "зелених" тарифрів до прозорих та конкурентних аукціонів. Система "зелених" аукціонів дозволяє: значно удосконалити механізм ціноутворення, зокрема встановлювати більш справедливу (ринкову) ціну на "чисту" електроенергію; здешевити вартість "зеленої" електроенергії для кінцевих споживачів; сорормувати конкуренцію між гравцями ринку; врегулювати планування бюджету; надати гарантії інвесторам щодо реалізації проектів та інше [4].

Якщо "зелені" тарифи на виробництво електроенергії з відновлюваних джерел енергії діють в Україні вже більше 10 років, то такий інструмент, як "зелені" облігації $€$ новинкою для вітчизняного фрінансового ринку. Досвід впровадження та фрінансування "зелених" проектів країн Європейського Союзу доводить, що так звані "зелені" облігації можуть бути есективним інструментом залучення коштів для фрінансування таких проектів.

"Зелена" облігація - це борговий інструмент, кошти від продажу якого спрямовуються виключно на фінансування "зелених" проектів. Такий фрінансовий інструмент призводить до здешевлення фрінансових ресурсів на "зелені" проекти та виступає мультиплікатором залучення інвестицій, оскільки вони можуть бути випущені багатьма суб'єктами (уряд, муніципалітети, банки, міжнародні фрінансові організації, спеціалізовані фонди тощо) [3].

Серед переваг випуску "зелених" облігацій є можливості доступу до ринку кліматичних фрінансів, у тому числі Зеленого кліматичного фонду (Green Climate 
ТОП-15 країн-е мітентів у 2019 р.

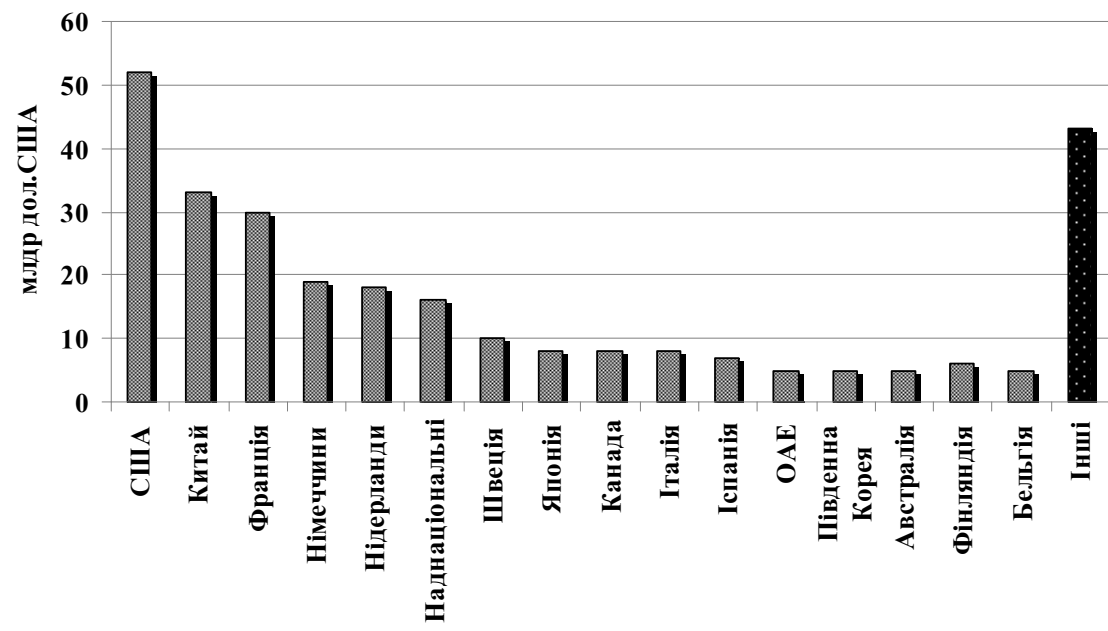

Рис. 1. тоП-15 країн-емітентів у 2019 р.

Джерело: [7].

Fund), який може надавати кошти на відповідні програми. Запровадження "зелених" облігацій в Україні сприятиме здешевленню фінансових ресурсів на реалізацію проектів "чистої" енергетики та дозволить мобілізувати потрібні інвестиційні ресурси.

Згідно з результатами аналізу, проведеного організацією Climate Bond Initiative [7], світовий обсяг емісії зелених облігацій та зелених позик у 2019 році склав 257,7 млрд дол. США, що на 51\% більше від остаточного показника за 2018 рік - 170,6 млрд дол. США. Зелені позики із загальної суми склали 4 млрд дол. США (4\%). Водночас загальна сукупність сертифікованих кліматичних облігацій пройшла важливий рубіж на 100 млрд дол. США. Відзначається, що на європейський ринок сек'юритизації припало $45 \%$ світової емісії, на ринок Азіатсько-Тихоокеанського регіону - 25\% та Північної Америки - 23\% (рис. 1).

За секторами найбільші обсяги коштів від емісії "зелених" облігацій спрямовуються у проекти відновлюваної енергетики та будівництва, сектори низькоемісійного транспорту, водних ресурсів, переробки та утилізації відходів, сільське, лісове та водне господарство.

Фінансові корпорації забезпечили випуск зелених облігацій на суму 55 млрд дол. США (2018 рік: 49,7 млрд дол. США), або $21 \%$ від загального обсягу річних. Два найкращих емітента - китайські фінансові установи, такі як ICBC та Industrial Bank. Французькі банки Credit Agricole та BNP Paribas займають третє та четверте місце, із загальною сумою у 4,5 млрд дол. США.

Очолили рейтинг ТОП-15 країн-емітентів США, Китай та Франція. Разом вони становили 44\% світової емісії в 2019 році. Американські емітенти внесли в загальну суму 51,3 млрд дол. США, тоді як їхні китайські та фрранцузькі колеги принесли на ринок 31,3 млрд дол. США та 30,1 млрд дол. США.

Сьогодні розробляється Концепція створення ринку "зелених" облігацій в Україні та Плану дій з їі реалізації, а також пакета необхідного первинного та вторинного законодавства. Держенергоефективності спільно із Нацкомісією з цінних паперів та фондового ринку та проектом GIZ "Консультування підприємств щодо енергоефективності" розробило норми до законопроек- ту № 2284 від 17.10.2019, якими передбачається запровадження "зелених" облігацій в Україні та встановлення правил для учасників цього ринку. Прийняття цього законопроекту дозволить запустити в Україні новий інструмент, який дасть поштовх впровадження зелених проектів, а також стане додатковим джерелом інвестиційних ресурсів на цілі сталого розвитку. Також підготовлено проект розпорядження Кабінету Міністрів України "Про схвалення Концепції запровадження ринку зелених облігацій в Україні та затвердження плану заходів щодо її реалізації", що опрацьовується разом із Міністерством енергетики та захисту довкілля України. Як показує світова практика, запуск ринку зелених облігацій дає країнам доступ до великого пулу інвесторів і сприяє виконанню цілей та міжнародних зобов' язань щодо цілей сталого розвитку. За розрахунком International Finance Company запуск ринку "зелених" облігацій дасть змогу Україні залучити 73 млрд дол. США до 2030 року.

Важливим напрямком удосконалення податкової політики в Україні стало підвищення з 1 січня 2019 року ставки екологічного податку за викиди двоокису вуглецю (СО2) стаціонарними джерелами з 0,41 грн/тонн до 10 грн/тонн з метою стимулювання підприємств-забруднювачів до зменшення забруднення навколишнього природного середовища, а також наближення до ставок за викиди парникових газів, що діють у країнах $Є С$. Такий механізм може стати дієвим інструментом акумуляції фрінансових ресурсів на потреби екологізації галузей економіки. Одним із варіантів може бути створення так званого "вуглецевого фонду", як окремої статті держбюджету. Головне при цьому забезпечити цільове використання цих коштів, включно на здійснення природоохоронних заходів із запобігання, зменшення та усунення забруднення довкілля.

Загалом розвиток "зеленої" економіки в Україні потребує активної підтримки держави за допомогою використання низки стимулюючих механізмів: регуляторних, організаційних, економічних, фінансових, інформаційних, комунікаційних, бюджетних та податкових. Підписання Угоди про асоціацію з Європейським Союзом є хорошим та ефективним поштовхом до озеленення української економіки, розвитку та підтримки нових "зелених" секторів економіки [9].

\section{ВИСНОВКИ}

За сучасних економічних умов, перспективи "озеленення" вітчизняної економіки, а це означає покращення галузевої та технологічної структури економіки України залежатимуть від ініціатив з боку уряду та інших ЦОВВ щодо удосконалення діючих та введення в дію нових стимулюючих механізмів.

Таким чином, аналіз теоретичних та практичних засад розвитку зелених фінансів, а також дієвості фрінансових інструментів у сфері розвитку "зеленої" економіки свідчить про недостатню розвиненість сектору зелених фрінансів в Україні. Ринок зелених фрінансів пе- 
ребуває на початковому етапі свого формування і характеризується обмеженістю фрінансових інструментів доступних для використання суб'єктами господарювання з метою фінансування зеленої модернізації та реалізації зелених проектів в різних галузях економіки.

На наш погляд, в Україні для забезпечення сталого розвитку та реалізації концепції "зеленої" економіки необхідно проводити подальшу роботу над удосконаленням правових, організаційних та фрінансових механізмів стимулювання залучення зелених інвестицій в перспективні, екологобезпечні сектори економіки, а також адаптувати прогресивний світовий досвід у даній сфрері. Запровадження дієвих фрінансових інструментів на кшталт зелених облігацій, зеленого кредитування, створення фондів фрінансування зелених проектів, оптимізація зелених тарифрів, введення аукціонів продажу енергії з ВДЕ сприятиме розвитку зеленої низьковуглецевої економіки в Україні.

\section{Література:}

1. "Зелені" інвестиції у сталому розвитку: світовий досвід та український контекст / Видання серії "Бібліотека Центру Разумкова" [Електронний ресурс]. - Режим доступу: http://razumkov.org.ua/uploads/article/ 2019_ZELEN_INVEST.pdf

2. Енергоефективність та "зелена" енергетика України: здобутки 5 останніх років та наступні цілі [Електронний ресурс]. - Режим доступу: http://saee.gov.ua/ sites/default/files/Savchuk_SAEE_22_11_2019.pdf

3. Запровадження зелених облігацій в Україні як інструмент залучення інвестицій в проекти з енергоефрективності та ВДЕ [Електронний ресурс]. - Режим доступу: https://saee.gov.ua/sites/default/files/ Green_bonds_Ukraine.pdf

4. Пояснювальна записка до проекту Закону про внесення змін до деяких законів України щодо забезпечення конкурентних умов виробництва електричної енергії з альтернативних джерел енергії (№ 8449- доопрацьований) [Електронний ресурс]. - Режим доступy: http://w1.c1.rada.gov.ua/pls/zweb2/webproc4_$1 ? \mathrm{pf} 3511=65076$

5. Стимулювання відновлюваної енергетики в Україні за допомогою "зеленого" тариф. [Електронний ресурс]. - Режим доступу: http://saee.gov.ua/documents/ green-tariff.pdf

6. Мороз В.В., Шепетько Р.І. Інституційне середовище неоіндустріалізації економіки України в світлі глобальних комплексних індексів "Економічний часописXXI" № 7-8 (2) 2015. С. 12-14 [Електронний ресурс] - Режим доступу: http://soskin.info/userfiles/file/ 2015/7-8_2_2015/Moroz_Shepetko.pdf

7. The official site of Green Bonds Market Summary 2019, Reports Februrary 2020: https://www.climatebonds.net/files/reports/2019_annual_highlights-final.pdf

8. Noh H. J. 2018. Financial Strategy to Accelerate Green Growth.ADBI Working Paper 866. Tokyo: Asian Development Bank Institute. Available: https:// www.adb.org/publications/financial-strategy-accelerate-green-growth

9. Moroz V.V. Ecological modernisation of the Ukrainian economy as a prerequisite for green growth // Modernization of socio-economic development of Ukraine: challenges and prospects: collective monograph / D.V.Klynovyi, E.B. Boychenko, I.O. Petrovskaya, V.V. Korneev, etc. - Lviv-Torun: Liha-Pres, 2019 - Availiable at: http://catalog.liha-pres.eu/index.php/liha-pres / catalog/view/25/275/611-1

\section{References:}

1. Razumkov Centre (2019), "Green investment in sustainable development: world experience and the Ukrainian context", available at: http://razumkov.org.ua/uploads/article/2019_ZELEN_INVEST.pdf (Accessed 1 March 2020).

2. State Agency on Energy Efficiency and Energy Saving of Ukraine (2019), "Energy efficiency and green energy of Ukraine: achievements of last 5 years and next goals", available at: http://saee.gov.ua/sites/default / files/Savchuk_SAEE_22_11_2019.pdf (Accessed 1 March 2020).

3. State Agency on Energy Efficiency and Energy Saving of Ukraine (2019), "Introducing green bonds in Ukraine as a tool for attracting investment in energy efficiency and renewable energy projects", available at: https://saee.gov.ua/sites/default/files/Green_bonds_Ukraine.pdf (Accessed 1 March 2020).

4. Verkhovna Rada of Ukraine (2019), "Explanatory Note to the Draft Law on Amendments to Certain Laws of Ukraine on Ensuring Competitive Conditions for Generation of Electricity from Alternative Energy Sources (No. 8449- revised)", available at: http://w1.c1.rada.gov.ua/pls/zweb2/webproc4_1?pf3511=65076 (Accessed 1 March 2020).

5. State Agency on Energy Efficiency and Energy Saving of Ukraine (2012), "Promoting renewable energy in Ukraine through a "green" tariff", available at: http:// saee.gov.ua/documents/green-tariff.pdf (Accessed 1 March 2020).

6. Moroz, V.V. and Shepet'ko, R.I. (2015), "The institutional environment of neo-industrialization of the Ukrainian economy in the light of global complex indices", Ekonomichnyy chasopys-XXI, vol. 7-8 (2), pp. 12-14, available at: http://soskin.info/userfiles/file/2015/78_2_2015/Moroz_Shepetko.pdf (Accessed 1 March $2 \overline{0} \overline{0})$.

7. The official site of Climate Bonds Initiative(2020), "Green Bonds Market Summary Reports Februrary" available at: https://www.climatebonds.net/files / reports/2019_annual_highlights-final.pdf (Accessed 1 March 2020).

8. Noh, H. J. (2018), "Financial Strategy to Accelerate Green Growth", ADBI Working Paper, [Online], vol. 866, Tokyo: Asian Development Bank Institute, available at: https://www.adb.org/publications/financial-strategyaccelerate-green-growth (Accessed 1 March 2020).

9. Moroz, V.V. Klynovyi, D.V., Boychenko, E. B Petrovskaya, I.O. and Korneev, V.V. (2019), "Ecological modernization of the Ukrainian economy as a prerequisite for green growth", Modernization of socio-economic development of Ukraine: challenges and prospects, pp. 179-198, available at: http://catalog.liha-pres.eu/ index.php/liha-pres/catalog/view/25/275/611-1 (Accessed 1 March 2020).

Стаття надійшла до редакчї 02.03.2020 p. 